\title{
MR angiography of midaortic syndrome
}

\author{
Anderanik Tomasian • Mayil S. Krishnam
}

Received: 10 May 2009/Revised: 7 June 2009 / Accepted: 24 June 2009 / Published online: 31 July 2009

(C) The Author(s) 2009. This article is published with open access at Springerlink.com

A 12-year-old boy presented with hypertension and intermittent lower extremity claudication. Breath-hold high spatial resolution MRA at 3.0 $\mathrm{T}$ (gradient recalled echo sequence; $10 \mathrm{ml}$ of Magnevist) revealed abdominal aortic coarctation (Fig. 1, thin long arrow), severely narrowed right renal artery and atrophy of the ipsilateral kidney (Fig. 1b, arrowhead), and hypertrophied inferior mesenteric artery (Fig. 1a, thick short arrow) feeding the superior mesenteric artery (Fig. 1a, thin short arrow) through the arc of Riolan (Fig. 1a, arrowhead). The child had previously undergone placement of an aorto-aortic graft (Fig. 1, thick long arrow).

Midaortic syndrome (MAS) is a rare disease caused by segmental narrowing of the abdominal or distal descending thoracic aorta associated with concomitant stenoses involving the renal (63\%) and visceral (33\%) arteries [1]. MAS can be congenital or acquired caused by giant cell or Takayasu arteritis, retroperitoneal fibrosis, Williams syndrome, fibromuscular dysplasia, neurofibromatosis, and mucopolysaccharidosis $[1,2]$. Noninvasive diagnosis is made by MRA or CT angiography [2]. Surgical bypass grafting is the optimal method of treatment [1].

A. Tomasian $(\bowtie) \cdot$ M. S. Krishnam

Department of Radiology, University of California - Los Angeles,

Peter V. Ueberroth Bldg., Suite 3371, 10945 Le Conte Ave.,

Los Angeles, CA 90095-7206, USA

e-mail: atomasian@mednet.ucla.edu
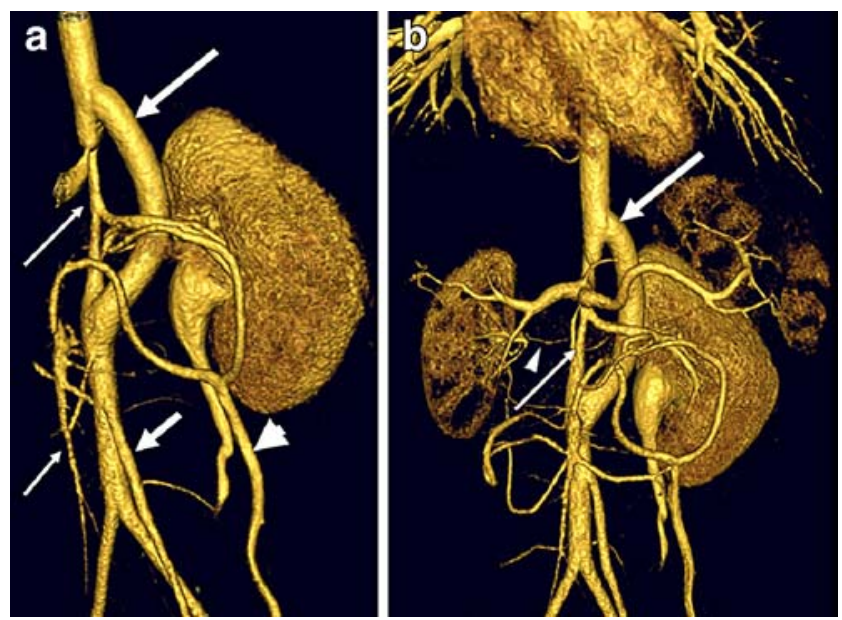

Fig. 1 3-D volume-rendered MR angiograms (Vitrea 3.6; Vital Images, Minneapolis, MN)

Open Access This article is distributed under the terms of the Creative Commons Attribution Noncommercial License, which permits any noncommercial use, distribution, and reproduction in any medium, provided the original author(s) and source are credited.

\section{References}

1. Delis KT, Gloviczki P (2005) Middle aortic syndrome: from presentation to contemporary open surgical and endovascular treatment. Perspect Vasc Surg Endovasc Ther 17:187-203

2. Celik T, Kursaklioglu H, Iyisoy A et al (2006) Hypoplasia of the descending thoracic and abdominal aorta: a case report and review of the literature. J Thorac Imaging 21:296-299 